\title{
Effects of Diet on Blood Pressure in Experimental Renal Hypertensive Rat
}

\author{
Hideo Ueda, M.D., Junichi IwaI, M.D., \\ and Hisakazu Yasuda, M.D.
}

\section{SUMmARY}

Many factors have been implicated in the etiology of hypertension. The experiments to be reported here were done to study the effects of diets on blood pressure in a total of 263 Dawley rats in which unilateral renal artery was constricted by silver clip and 82 normal rat served as controls.

As regards the environmental factors, experiment I was done under the natural condition while experiment II was made under the condition of constant temperature and constant humidity.

In experiment I, both normal control and renal hypertensive rats were divided into 9 groups respectively and fed various experimental diets by the combinations of protein, fat and salt according to the experimental design. In experiment II, they were divided into 5 groups respectively by the combination of protein and salt.

From these experiments, it was observed that low protein diet combined with high salt causes significant elevation in blood pressure of Goldblatt hypertensive rats compared to the other experimental diet, while not in the normal control rats fed the diets of similar composition. There were no significant differences in blood pressure elevation between two environmental conditions.

\section{Additional Indexing Words :}

High salt diet Low protein diet Fat diet Renal artery constriction Cardiac hypertrophy Environmental factor

T $\mathrm{T}$ is well known that many factors have been implicated in the etiology of hypertension. These include renal, endocrine, and neurogenic factors and disturbances of electrolyte. Genetic, environmental and dietary factors are also considered to play an important role in the development of hypertension. Because of the universality of these effective factors, their influence deserves broad and careful study. However, knowledge about these components of essential hypertension has come mostly from clinical or epidemiological data. Dahl has shown that the incidence of hypertension can be correlated with the salt intake of various peoples in different geographic areas or among

From the Second Department of Internal Medicine, Faculty of Medicine, University of Tokyo, Tokyo.

Received for publication November 10, 1968. 
different races. ${ }^{2)}$ It is also reported that in Japan the incidence of hypertension is high in some areas where pcoplc take more amount of rice diet with high salt. ${ }^{1)}$ In these epidemiological findings, there are many factors that modify the blood pressure. Therefore, the experiments were desired to be done in the strain of animals under the constant condition as purely as possible.

It is established that hypertension can be induced in the experimental animals by the continued administration of salt. Furthermore, Dahl demonstrated the genetic factors by segregating the susceptible strain of rat to produce salt hypertension. ${ }^{3-5}$ ) However, in respect of protein and fat, their role in the etiology of hypertension remains obscure.

This experiment were done to investigate the effects of various diets on blood pressure in normal and experimental renal hypertensive rats.

\section{Methods}

\section{Experiment $I$}

Rats employed in this experiment were 838 females of the Dawley strain weighing 90 to $100 \mathrm{Gm}$. They were given a commercial food, prepared by Oriental Co., Tokyo. Tap water was always available ad libitum until the beginning of experimental-diet period. Blood pressure was determined by the microphonic cuff method. ${ }^{6), 7)}$

Blood pressure and weight were estimated twice a week throughout the study. After establishing controls for blood pressure, one renal artery constriction and unilateral nephrectomy were performed of 786 of the rats by two stage process. In

Table I. Glassification of Groups

(Experiment I)

\begin{tabular}{|c|c|c|c|}
\hline \multicolumn{2}{|c|}{ Groups } & \multirow{2}{*}{ Diets } & \multirow{2}{*}{ Remarks } \\
\hline Hypertensive & Normal & & \\
\hline A & a & whale meat, lard, $1 \%$ salt solution & high protcin, high fat, high salt \\
\hline $\mathrm{B}$ & $\mathrm{b}$ & whale meat, lard, tap water & high protein, high salt, low salt \\
\hline $\mathrm{C}$ & c & whale meat, $1 \%$ salt solution & high protien, law fat, high salt \\
\hline $\mathrm{D}$ & $\mathrm{d}$ & whale meat, tap water & high protein, low fat, low salt \\
\hline $\mathbf{E}$ & $\mathrm{e}$ & rice, lard, $1 \%$ salt solution & low protein, high fat, high salt \\
\hline$F$ & $f$ & rice, lard, tap water & low protein, high fat, low salt \\
\hline $\mathrm{G}$ & $\mathrm{g}$ & rice, $1 \%$ salt solution & low protein, low fat, high salt \\
\hline $\mathrm{H}$ & $\mathrm{h}$ & rice, tap water & low protein, low fat, low salt \\
\hline I & $\mathrm{i}$ & oriental food, tap water & Control \\
\hline
\end{tabular}


the first stage, left renal artery was constricted by silver clip under ether anesthesia. One week later, the right kidney was removed. Consistent elevation of blood pressure with its fluctuation within $\pm 10 \mathrm{~mm}$. Hg for more than 2 weeks was obtained 5 weeks after operation in 166 of the 786 rats. These 166 rats were assigned to experimental groups. They were divided into 9 groups (Table I, A through I) at random and switched to experimental diets according to the experimental plan. The initial blood pressure was balanced to approximately equal in each group. These groups were referred to as the "hypertensive group". Fifteen-two normal rats served as controls and they were also divided into 9 groups and were given the same diets as hypertensive groups. These groups were referred to as the "normal group". The compositions of experimental diets were shown in Table II. All the groups were given the experimental diets which were nutritionally sufficient every other day. The calculated amounts of daily food intake were shown in Table III. The high-salt groups were given $1 \%$ salt solution ad libitum and low-salt groups were given tap water ad libitum. At the end of 9 weeks experimental-diet period, all the rats were

Table II. Composition of Experimental Diets

(per $100 \mathrm{Gm}$.)

\begin{tabular}{|c|c|c|c|c|}
\hline & Whale meat & Rice & Lard & Oriental food \\
\hline Calorie & 109 Cal. & $340 \mathrm{Cal}$ & $899 \mathrm{Cal}$ & 162 Cal. \\
\hline Water & $72.76 \mathrm{Gm}$ & $13.12 \mathrm{Gm}$ & & $7.0 \mathrm{Gm}$ \\
\hline Protein & $24.36 \mathrm{Gm}$ & $6.58 \mathrm{Gm}$ & $0.20 \mathrm{Gm}$ & $24.2 \mathrm{Gm}$ \\
\hline Fat & $1.24 \mathrm{Gm}$ & $0.41 \mathrm{Gm}$ & $99.80 \mathrm{Gm}$ & $5.5 \mathrm{Gm}$ \\
\hline $\mathrm{Ca}$ & $4 \mathrm{mg}$. & $24 \mathrm{mg}$. & & $1.76 \mathrm{Gm}$ \\
\hline $\mathbf{P}$ & $195 \mathrm{mg}$ & $147 \mathrm{mg}$. & & 1.04 Gm. \\
\hline $\mathrm{NaCl}$ & $86 \mathrm{mg}$. & & & \\
\hline Vit. $B_{1}$ & $0.10 \mathrm{mg}$. & $0.10 \mathrm{mg}$ & $0.02 \mathrm{mg}$. & $0.9 \mathrm{mg}$ \\
\hline Vit. $\mathrm{B}_{2}$ & $0.10 \mathrm{mg}$ & $0.4 \mathrm{mg}$. & $0.02 \mathrm{mg}$ & $0.8 \mathrm{mg}$. \\
\hline
\end{tabular}

Table III. Doses of Diet per Day

\begin{tabular}{|c|c|c|c|c|}
\hline & Whale meat & Rice & Lard & Oriental food \\
\hline Protein & $14.6 \mathrm{Gm}$ & $1.1 \mathrm{Gm}$ & & $7.2 \mathrm{Gm}$ \\
\hline Fat & $0.74 \mathrm{Gm}$ & $0.08 \mathrm{Gm}$ & $9.9 \mathrm{Gm}$ & $1.8 \mathrm{Gm}$ \\
\hline Sugar & $0.01 \mathrm{Gm}$ & $15.5 \mathrm{Gm}$ & & $0.02 \mathrm{Gm}$ \\
\hline Vit. $B_{1}$ & $0.05 \mathrm{mg}$. & $0.02 \mathrm{mg}$ & $0.02 \mathrm{mg}$ & $0.3 \mathrm{mg}$. \\
\hline Vit. $B_{2}$ & $0.05 \mathrm{mg}$ & $0.01 \mathrm{mg}$ & $0.02 \mathrm{mg}$ & $0.3 \mathrm{mg}$. \\
\hline Calorie & 65 Cal. & 62 Cal. & 84 Cal. & 54 Cal. \\
\hline
\end{tabular}


sacrificed and heart, kidney and other organs were removed and weighed.

\section{Experiment $I I$}

Rats employed in this study were 320 females of the Dawley strain weighing 90 to $100 \mathrm{Gm}$. They were housed in air-conditioned room (room temperature 22$24^{\circ} \mathrm{C}$, humidity $50 \pm 5 \%$ ), 4 to 6 animals per cage, with free access to drinking water and foot. Renal artery constriction and uninephrectomy was performed by the same process described above. Consistent elevated blood pressures with its fluctuation within $\pm 10 \mathrm{~mm}$.Hg for more than 2 weeks were obtained in 97 of the 162 hypertensive rats. These 97 rats were assigned to experimental groups by the same method as in Experiment I. They were divided into 5 groups (A through $\mathrm{E}$ ) and switched to experimental diets. Thirty normal rats served as controls. All the groups in this were given the diets every day. The classifications and their experimental diets were shown in Table IV.

Table IV. Classification of Groups

(Experiment II)

\begin{tabular}{c|c|c|c}
\hline \multicolumn{2}{c|}{ Groups } & Diets & Remarks \\
\hline Hypertensive & Normal & & high protein, high salt \\
\hline A & a & whale meat, 1\% salt solution & high protein, low salt \\
\hline B & b & whale meat, tap water & low protein, high salt \\
\hline C & c & rice, 1\% salt solution & low protein, low salt \\
\hline D & d & rice, tap water & Control \\
\hline E & e & Oriental food, tap water &
\end{tabular}

Table V. The Changes in Blood

\begin{tabular}{c|c|c|c|c}
\hline \multirow{2}{*}{ Group } & \multicolumn{2}{|c|}{ Before renal artery constriction } & \multicolumn{2}{|c}{ Before feeding of experimental diet } \\
\cline { 2 - 5 } & $\begin{array}{c}\text { Blood pressure } \\
\text { mm.Hg }\end{array}$ & $\begin{array}{c}\text { Body weight } \\
\text { Gm. }\end{array}$ & $\begin{array}{c}\text { Blood pressure } \\
\text { mm.Hg }\end{array}$ & $\begin{array}{c}\text { Body weight } \\
\text { Gm. }\end{array}$ \\
\hline A & $107.1 \pm 3.3$ & $99.6 \pm 6.1$ & $150.2 \pm 4.5$ & $190.4 \pm 5.9$ \\
\hline B & $103.6 \pm 3.8$ & $100.6 \pm 5.2$ & $148.1 \pm 3.1$ & $187.6 \pm 7.7$ \\
\hline G & $116.8 \pm 4.2$ & $101.2 \pm 7.2$ & $150.8 \pm 5.2$ & $191.4 \pm 8.8$ \\
\hline D & $111.4 \pm 2.9$ & $101.3 \pm 6.5$ & $152.1 \pm 4.5$ & $182.4 \pm 6.5$ \\
\hline E & $106.5 \pm 3.8$ & $98.6 \pm 8.1$ & $158.2 \pm 3.9$ & $190.1 \pm 5.9$ \\
\hline F & $107.4 \pm 5.1$ & $100.6 \pm 8.3$ & $153.1 \pm 2.1$ & $189.4 \pm 7.1$ \\
\hline G & $104.6 \pm 4.9$ & $94.6 \pm 5.4$ & $155.1 \pm 4.4$ & $200.4 \pm 6.8$ \\
\hline H & $108.1 \pm 6.1$ & $98.8 \pm 7.5$ & $153.2 \pm 3.8$ & $198.2 \pm 6.1$ \\
\hline I & $107.6 \pm 7.2$ & $103.1 \pm 6.9$ & $144.3 \pm 3.2$ & $192.6 \pm 7.5$ \\
\hline
\end{tabular}




\section{Results}

\section{Experiment $I$}

I) Effects of diet on blood pressure in hypertensive groups

The changes in blood pressure and weight before and after experimental diet were shown in Table $\mathrm{V}$ and Fig. 1. At the end of experimental-diet period, the blood pressure of group $\mathrm{E}$ and $\mathrm{G}$ was significantly $(\mathrm{p}<0.01)$ ele-

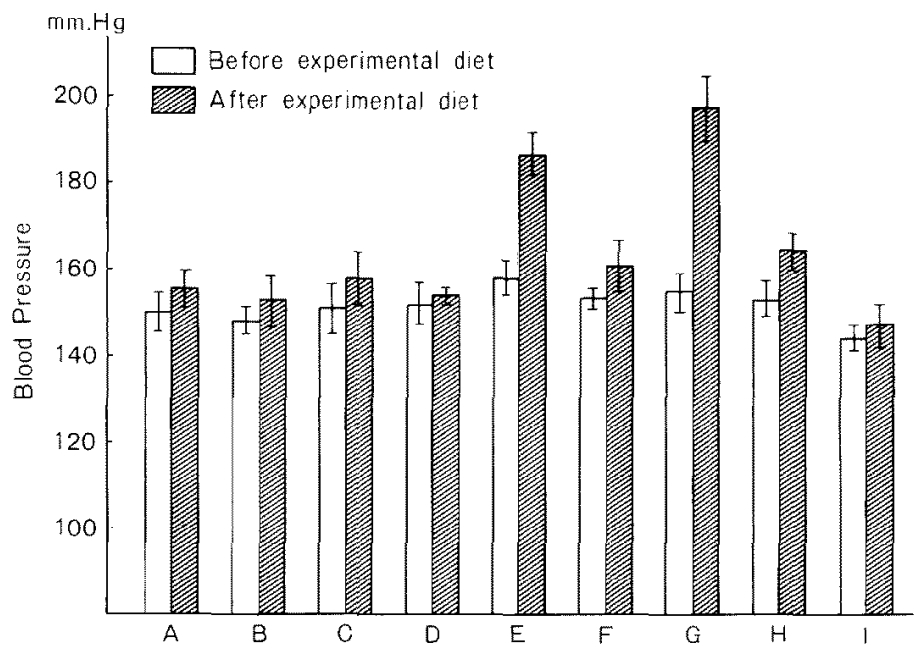

Fig. 1. The effect of experimental diet on blood pressure in experimental hypertensive groups (Experiment I).

Pressure and Body Weight in Hypertensive Groups

(Experiment I)

\begin{tabular}{|c|c|c|c|}
\hline \multicolumn{2}{|c|}{ After experimental diet } & \multirow{2}{*}{$\begin{array}{l}\text { Number of the elevated } \\
\text { case in blood pressure }\end{array}$} & \multirow{2}{*}{ 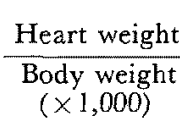 } \\
\hline $\begin{array}{l}\text { Blood pressure } \\
\text { mm.Hg }\end{array}$ & $\begin{array}{l}\text { Body weight } \\
\text { Gm. }\end{array}$ & & \\
\hline $155.0 \pm 4.9$ & $198.1 \pm 8.4$ & $6 / 20(30.3 \%)$ & $4.1 \pm 0.4$ \\
\hline $152.8 \pm 5.9$ & $206.5 \pm 9.1$ & $2 / 19(10.5 \%)$ & $4.5 \pm 0.5$ \\
\hline $158.1 \pm 6.4$ & $198.6 \pm 8.3$ & $6 / 19(31.5 \%)$ & $4.0 \pm 0.2$ \\
\hline $153.8 \pm 2.1$ & $189.6 \pm 9.4$ & $3 / 18(16.7 \%)$ & $3.8 \pm 0.3$ \\
\hline $187.4 \pm 5.6$ & $201.4 \pm 10.1$ & $10 / 19(52.6 \%)$ & $5.1 \pm 0.4$ \\
\hline $161.0 \pm 5.8$ & $200.4 \pm 9.8$ & $5 / 18(27.7 \%)$ & $3.6 \pm 0.7$ \\
\hline $197.5 \pm 7.2$ & $196.6 \pm 8.4$ & $11 / 19(57.8 \%)$ & $5.2 \pm 0.6$ \\
\hline $164.2 \pm 4.3$ & $196.8 \pm 8.4$ & $5 / 16(31.3 \%)$ & $3.7 \pm 0.5$ \\
\hline $147.2 \pm 4.8$ & $207.8 \pm 8.6$ & $4 / 18(22.2 \%)$ & $3.6 \pm 0.3$ \\
\hline
\end{tabular}


vated than that of other groups. But no significant difference in blood pressure was observed between group $\mathrm{E}$ and $\mathrm{G}$ (Table V, Fig. 1). There were no significant elevation in blood pressure at the beginning and end of the experimental-diet period except group E and G. Groups on a low-protein diet combined with high salt only rose to significant hypertensive level. Fat did not influence blood pressure in this experiment.

The number of elevated cases of $30 \mathrm{~mm} . \mathrm{Hg}$ or more in blood pressure was shown in Table V. The low protein-low fat-high salt group showed a $57.8 \%$ in elevation rate. The low protein-high fat-high salt group showed $52.6 \%$ increase in elevation rate. These 2 groups showed an increase in elevation rate

Table VI. The Changes in Blood Pressure

\begin{tabular}{c|c|c|c|c}
\hline \multirow{2}{*}{ Group } & \multicolumn{2}{|c|}{ At the 3rd week } & \multicolumn{2}{c}{ Before feeding of experimental diet } \\
\cline { 2 - 5 } & $\begin{array}{c}\text { Blood pressurc } \\
\mathrm{mm} . \mathrm{Hg}\end{array}$ & $\begin{array}{c}\text { Body weight } \\
\text { Gm. }\end{array}$ & $\begin{array}{c}\text { Blood pressure } \\
\text { mm.Hg }\end{array}$ & $\begin{array}{c}\text { Body weight } \\
\text { Gm. }\end{array}$ \\
\hline $\mathrm{a}$ & $104.7 \pm 4.5$ & $101.5 \pm 6.5$ & $118.6 \pm 5.5$ & $194.1 \pm 6.1$ \\
\hline $\mathrm{b}$ & $106.6 \pm 5.2$ & $98.6 \pm 3.5$ & $116.3 \pm 3.1$ & $186.5 \pm 7.2$ \\
\hline $\mathrm{c}$ & $103.3 \pm 7.2$ & $104.3 \pm 7.1$ & $113.2 \pm 3.5$ & $196.5 \pm 3.9$ \\
\hline $\mathrm{d}$ & $112.4 \pm 4.6$ & $100.6 \pm 5.4$ & $117.5 \pm 3.0$ & $190.5 \pm 4.7$ \\
\hline $\mathrm{e}$ & $107.5 \pm 3.9$ & $99.1 \pm 4.5$ & $116.4 \pm 2.5$ & $192.3 \pm 5.1$ \\
\hline $\mathrm{f}$ & $106.1 \pm 4.9$ & $105.3 \pm 7.5$ & $117.5 \pm 4.0$ & $186.5 \pm 7.2$ \\
\hline $\mathrm{g}$ & $113.4 \pm 5.3$ & $96.5 \pm 5.7$ & $119.5 \pm 3.2$ & $196.5 \pm 4.3$ \\
\hline $\mathrm{h}$ & $100.5 \pm 6.8$ & $95.4 \pm 3.6$ & $119.6 \pm 3.8$ & $193.2 \pm 5.1$ \\
\hline $\mathrm{i}$ & $104.5 \pm 7.9$ & $97.8 \pm 7.1$ & $110.5 \pm 4.2$ & $195.1 \pm 3.7$ \\
\hline
\end{tabular}

Table VII. The Changes in Blood Pressure

\begin{tabular}{c|c|c|c|c}
\hline \multirow{2}{*}{ Group } & \multicolumn{2}{|c|}{ Before renal artery constriction } & \multicolumn{2}{c}{ Before feeding of experimental diet } \\
\cline { 2 - 5 } & $\begin{array}{c}\text { Blood pressure } \\
\text { mm.Hg }\end{array}$ & $\begin{array}{c}\text { Body weight } \\
\text { Gm. }\end{array}$ & $\begin{array}{c}\text { Blood pressure } \\
\text { mm.Hg }\end{array}$ & $\begin{array}{c}\text { Body weight } \\
\text { Gm. }\end{array}$ \\
\hline A & $103.5 \pm 5.6$ & $99.6 \pm 6.5$ & $147.2 \pm 3.2$ & $174.8 \pm 5.9$ \\
\hline B & $108.2 \pm 3.7$ & $92.6 \pm 7.4$ & $150.8 \pm 3.4$ & $184.2 \pm 6.3$ \\
\hline C & $99.4 \pm 3.9$ & $89.6 \pm 7.2$ & $146.8 \pm 1.8$ & $192.6 \pm 4.5$ \\
\hline D & $104.9 \pm 4.5$ & $98.6 \pm 5.1$ & $148.4 \pm 4.2$ & $204.6 \pm 7.6$ \\
\hline E & $101.6 \pm 5.4$ & $104.3 \pm 4.9$ & $143.6 \pm 2.6$ & $189.6 \pm 5.7$ \\
\hline
\end{tabular}


of significance compared to other groups.

There was no significant difference in the effects of the various diets on body weight.

Heart weight/body weight ratio is shown in Table V. Group E and $\mathrm{G}$ showed a significantly greater ratio than did the controls. Examination of the tissues of these rats revealed cardiac hypertrophy.

II) Effects of diets on blood pressure in normal groups

The changes in blood pressure and body weight were shown in Table VI and Fig. 2. There were a slight rise in blood pressure of no significance at the beginning and end of the experimental diet period.

and Body Weight in Normal Groups

(Experiment I)

\begin{tabular}{|c|c|c|c|}
\hline \multicolumn{2}{|c|}{ After experimental diet } & \multirow{2}{*}{$\begin{array}{l}\text { Number of the elevated } \\
\text { case in blood pressure }\end{array}$} & \multirow{2}{*}{$\begin{array}{c}\text { Heart weight } \\
\text { Body weight } \\
(\times 1,000)\end{array}$} \\
\hline $\begin{array}{l}\text { Blood pressure } \\
\mathrm{mm} . \mathrm{Hg}\end{array}$ & $\begin{array}{l}\text { Body weight } \\
\text { Gm. }\end{array}$ & & \\
\hline $122.4 \pm 3.6$ & $198.2 \pm 7.1$ & $0 / 6 \quad(0 \%)$ & $2.9 \pm 0.4$ \\
\hline $126.5 \pm 4.3$ & $195.1 \pm 6.5$ & $(0 \%)$ & $3.1 \pm 0.3$ \\
\hline $123.5 \pm 2.8$ & $204.3 \pm 7.1$ & $(0 \%)$ & $2.9 \pm 0.3$ \\
\hline $126.1 \pm 3.1$ & $196.5 \pm 5.1$ & $(0 \%)$ & $3.0 \pm 0.6$ \\
\hline $128.1 \pm 4.2$ & $198.5 \pm 5.7$ & $1 / 6(16.7 \%)$ & $3.0 \pm 0.5$ \\
\hline $135.2 \pm 3.6$ & $190.4 \pm 7.2$ & $(0 \%)$ & $3.1 \pm 0.4$ \\
\hline $127.4 \pm 3.2$ & $204.5 \pm 6.5$ & $1 / 6(16.7 \%)$ & $3.2 \pm 0.6$ \\
\hline $126.8 \pm 4.5$ & $200.5 \pm 4.9$ & $(0 \%)$ & $3.1 \pm 0.3$ \\
\hline $127.1 \pm 5.1$ & $199.8 \pm 4.4$ & $0 / 6 \quad(0 \%)$ & $2.6 \pm 0.4$ \\
\hline
\end{tabular}

and Body Weight in Hypertensive Groups

(Experiment II)

\begin{tabular}{|c|c|c|c|}
\hline \multicolumn{2}{|c|}{ After experimental diet } & \multirow{2}{*}{$\begin{array}{l}\text { Number of the elevated } \\
\text { case in blood pressure }\end{array}$} & \multirow{2}{*}{$\begin{array}{c}\text { Heart weight } \\
\text { Body weight } \\
(\times 1,000)\end{array}$} \\
\hline $\begin{array}{l}\text { Blood pressure } \\
\mathrm{mm} . \mathrm{Hg}\end{array}$ & $\begin{array}{l}\text { Body weight } \\
\text { Gm. }\end{array}$ & & \\
\hline $170.8 \pm 4.9$ & $189.6 \pm 8.1$ & $6 / 20(30.3 \%)$ & $4.4 \pm 0.4$ \\
\hline $161.8 \pm 7.2$ & $200.6 \pm 7.7$ & $3 / 19(15.8 \%)$ & $3.1 \pm 0.4$ \\
\hline $194.0 \pm 6.2$ & $199.4 \pm 7.3$ & $9 / 20(45.0 \%)$ & $5.6 \pm 0.3$ \\
\hline $173.2 \pm 4.6$ & $218.8 \pm 6.5$ & $3 / 19(15.8 \%)$ & $4.9 \pm 0.5$ \\
\hline $152.4 \pm 5.4$ & $206.6 \pm 5.8$ & $2 / 19(10.5 \%)$ & $3.2 \pm 0.7$ \\
\hline
\end{tabular}


Heart weight/body weight ratio showed no significant difference in each group (Table VI). The number of elevated cases of $30 \mathrm{~mm} . \mathrm{Hg}$ in blood pressure was shown in Table VI.

\section{Experiment II}

I) Effects of diet on blood pressure in hypertensive groups

The changes in blood pressure and weight were shown in Table VII and Fig. 3.

The average blood pressure of the group $\mathrm{C}$ on low protein-high salt diet was $194.0 \mathrm{~mm} . \mathrm{Hg}$ at the end of experimental diet period.

The blood pressure of this group showed significant elevation than that of other groups. The number of elevated cases of $30 \mathrm{~mm} . \mathrm{Hg}$ or more in

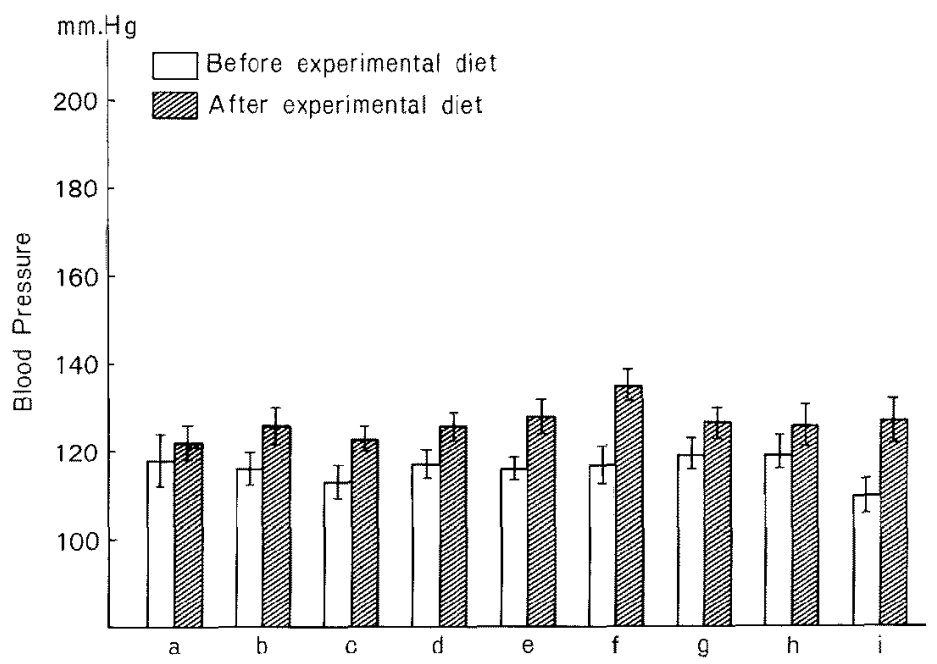

Fig. 2. The effect of experimental diet on blood pressure in normal groups (Experiment I).

Table VIII. The Changes in Blood Pressure

\begin{tabular}{|c|c|c|c|c|}
\hline \multirow[b]{2}{*}{ Group } & \multicolumn{2}{|c|}{ At the 3 rd week } & \multicolumn{2}{|c|}{ Before feeding of experimental diet } \\
\hline & $\begin{array}{c}\text { Blood pressure } \\
\text { mm.Hg }\end{array}$ & $\begin{array}{l}\text { Body weight } \\
\text { Gm. }\end{array}$ & $\begin{array}{c}\text { Blood pressure } \\
\text { mm.Hg }\end{array}$ & $\begin{array}{c}\text { Body weight, } \\
\text { Gm. }\end{array}$ \\
\hline a & $96.6 \pm 5.1$ & $93.5 \pm 3.9$ & $105.2 \pm 3.2$ & $170.1 \pm 5.3$ \\
\hline $\mathrm{b}$ & $102.7 \pm 6.5$ & $98.5 \pm 4.2$ & $110.1 \pm 3.5$ & $165.5 \pm 3.9$ \\
\hline$c$ & $106.3 \pm 3.1$ & $100.4 \pm 3.2$ & $106.3 \pm 3.4$ & $190.4 \pm 3.6$ \\
\hline $\mathrm{d}$ & $103.5 \pm 2.9$ & $96.1 \pm 5.1$ & $103.5 \pm 4.4$ & $198.4 \pm 4.2$ \\
\hline $\mathrm{e}$ & $100.6 \pm 4.2$ & $102.5 \pm 4.3$ & $102.1 \pm 3.6$ & $190.3 \pm 4.5$ \\
\hline
\end{tabular}


blood pressure was shown in Table VII. The low protcin-high salt group had a $45.0 \%$ increase in elevation rate significantly.

There were no significant changes in body weight. The mortality of the group on high protein-high salt diet was greater than that of other groups.

II) Effects of diet on blood pressure in normal groups

The normal groups had a slight rise in blood pressure at the beginning and end of the experimental diet period but they were of no significant differences in each group. The number of elevated case in blood pressure was shown in Table VIII and Fig. 4.

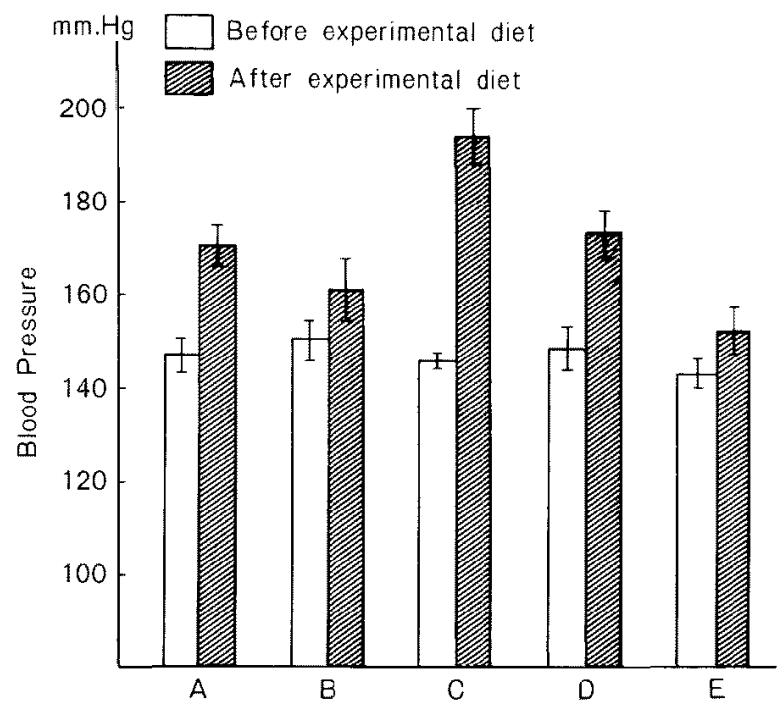

Fig. 3. The effect of experimental diet on blood pressure in experimental hypertensive groups (Experiment II).

and Body Weight in Normal Groups

(Experiment II)

\begin{tabular}{|c|c|c|c|}
\hline \multicolumn{2}{|c|}{ After experimental diet } & \multirow{2}{*}{$\begin{array}{l}\text { Number of the elevated } \\
\text { casc in blood pressure }\end{array}$} & \multirow{2}{*}{$\begin{array}{c}\text { Heart weight } \\
\text { Body weight } \\
(\times 1,000)\end{array}$} \\
\hline $\begin{array}{l}\text { Blood pressure } \\
\text { mm.Hg }\end{array}$ & $\begin{array}{l}\text { Body weight } \\
\text { Gm. }\end{array}$ & & \\
\hline $120.4 \pm 3.5$ & $190.5 \pm 7.5$ & $1 / 6(16.7 \%)$ & $2.8 \pm 0.4$ \\
\hline $125.3 \pm 2.9$ & $189.5 \pm 4.9$ & $0 / 6 \quad(0 \%)$ & $3.1 \pm 0.3$ \\
\hline $121.7 \pm 3.9$ & $205.3 \pm 7.1$ & $1 / 6(16.7 \%)$ & $3.4 \pm 0.2$ \\
\hline $123.7 \pm 4.1$ & $214.5 \pm 5.8$ & $0 / 6 \quad(0 \%)$ & $3.0 \pm 0.3$ \\
\hline $119.5 \pm 5.3$ & $210.3 \pm 4.4$ & $0 / 6 \quad(0 \%)$ & $2.9 \pm 0.4$ \\
\hline
\end{tabular}




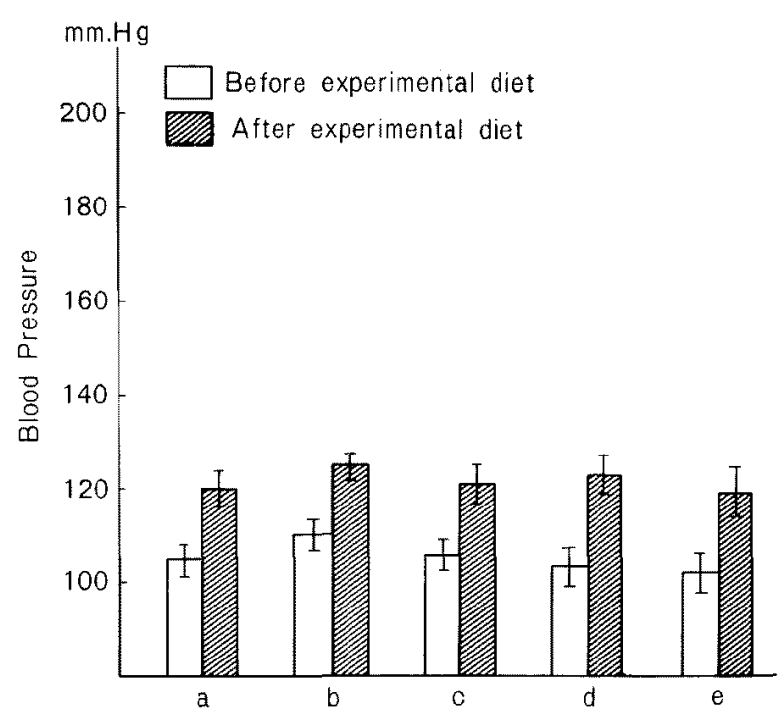

Fig. 4. The effect of experimental diet on blood pressure in normal groups (Experiment II).

\section{Discussion}

There have been few experimental evidences pointing to a relation between the development of hypertension and a diet intake. The experiments to be reported here were done to study the effects of diets on blood pressure under the constant conditions.

Gregg ${ }^{8)}$ reported that the elevation in blood pressure was observed in three fourths of the rats following renal artery constriction and unilateral nephrectomy, while a half in this experiment. There are several factors that modify the elevation in blood pressure, including: (a) process of subtotal nephrectomy, (b) the age at which experiment is made, (c) the degree of renal artery constriction, and (e) being or not being of intact kidney. This experiment was done under the same conditions in all respects except diets in order to identify with certainty the influence of dietary factor.

In experiment I, the rats were fed the experimental diets, that is, whale meat as high protein diet and rice as low protein diet every other day, while in experiment II they were fed every day. But the amount of diets per day was almost equal in these 2 experiments and they gained weight equally.

As regards the environmental factors, experiment I was done under the natural condition, while experiment II was made under the condition of con- 
stant temperature and constant humidity. But there seemed to be no essential difference in the results obtained in these experiments.

It has now been established that salt plays a role in the development of hypertension in the strain which has genetic factor. In our studies, same tendency of blood pressure elevation was observd in experimental renal hypertensive rats after ingesting low protein-high salt diets. Kolff and Page ${ }^{\text {), 10) }}$ reported that protein had no influence upon blood pressure in the experimental renal hypertensive dogs. But Muirhead et al. ${ }^{11)}$ suggest that high salt-high protein diet may cause the elevation of blood pressure in the nephrectomized rats. It is known that incidence of hypertension is less in the cases with liver cirrhosis or other hepatic demage, clinically. Hartroft et al. ${ }^{14)}$ reported that the diet on choline deficiency did cause the elevation in blood pressure. Although renal pathological changes are suggestive as a cause of this hypertension, the exact mechanism is still unknown.

Selye et al. $^{15)}$ reported that rats on high fat diet showed an adrenal hypertrophy. And there was a report that fat causes the elevation of blood pressure in rats. But in this experiment, fat did not cause further elevation of blood pressure.

Contrary to the result of hypertensive rats, there were no significant effects of diet on blood pressure in normal rats. In normal rats, high salt only did not operate as developing factor. Dahl suggested that the genetic factor plays an important role in the etiology of salt hypertension in rats.

Hilker et al. ${ }^{17)}$ observed the elevation of blood pressure with cardiac and renal hypertrophy as well as distinct renal pathology in normal rats fed a similar diet as Japanese one. In his experiment, he concluded that the high intake of sodium or its intake in relation to potassium modifies the blood pressure elevation but that it is not a primary causative factor.

In this experimental study, it is definite that the renal artery constriction and unilateral nephrectomy operate as the basic etiologic factors. In addition, the group on the low protein (rice) diets showed more elevated pressure than the group on the high protein diets (whale meat) in hypertensive rats. Because of the preliminary experiment, it remains unsettled which components of diets are important as a developing factor or accelerating factor to elevate the blood pressure and why these diets are more effective on hypertensive rats than normal rats. Further detailed studies should be necessary.

\section{REFERENCES}

1. Nakazawa, F.: J. Jap. Soc. Int. Med. 40: 487, 1951 (in Japanese).

2. Dahl, L. K.: Essential Hypertension, an International Symposium, Berlin, Springer, 1960. 
3. Dahl, L. K.: J. Exp. Med. 114: 231, 1961.

4. Dahl, L. K.: Nature 194: 480, 1962.

5. Dahl, L. K. and Schackow, E.: Cand. Med. Ass. J. $90: 155,1964$.

6. Friedman, M. and Freed, S. C.: Proc. Soc. Exp. Biol. Med. 70: 670, 1949.

7. Olmsted, F., Corcoran, A. G., and Page, I. H.: Circulation 3: 722, 1951.

8. Gregg, D. E.: Methods in Medical Research 5: 259, 1952.

9. Kolff, W. J. and Page, I. H.: Am. J. Physiol. 178: 69, 1954.

10. Kolff, W. J. and Page, I. H.: Am. J. Physiol. 181 : 580, 1955.

11. Muirhead, E. E., Stirman, J. A., and Jones, F.: Circulat. Res. 7: 68, 1953.

12. Handler, P. and Bernheim, F.: Am. J. Physiol. 162: 189, 1950.

13. Loyke, H. F.: Am. J. M. Sc. 230: 627, 1955.

14. Hartroft, W. S. and Best, C. H.: Brit. Med. J. 1: 423, 1949.

15. Selye, H.: The Physiology and Pathology of Exposure to Stress, Acta Inc., Montreal, 1950.

16. Renaud, S. and Allard, C.: Canad. Med. Ass. J. 88: 1275, 1963.

17. Hilker, D. M., Wenkam, N. S., and Lichton, I. J.: J. Nutrition 87: 371, 1965. 